\title{
Chemical and Biological Properties of Soils Under Maize-Cowpea Cropping Systems in Conservation Agriculture
}

\author{
John S. K. Banda ${ }^{1}$, Alice M. Mweetwa ${ }^{2}$, Munsanda Ngulube ${ }^{2} \&$ Elijah Phiri $^{2}$ \\ ${ }^{1}$ Zambia Agricultural Research Institute, Chilanga, Zambia \\ ${ }^{2}$ Department of Soil Sciences, School of Agricultural Sciences, University of Zambia, Lusaka, Zambia \\ Correspondence: Alice M. Mweetwa, Department of Soil Sciences, School of Agricultural Sciences, University of \\ Zambia, Box 32379, Lusaka, Zambia. Tel: 260-971-803-918. E-mail: alicemweetwa@yahoo.com
}

Received: March 6, $2018 \quad$ Accepted: April 2, $2018 \quad$ Online Published: April 15, 2018
doi:10.5539/jas.v10n5p100
URL: https://doi.org/10.5539/jas.v10n5p100

\begin{abstract}
The paper reports findings from an evaluation of the effects of selected chemical and biological properties of soils under maize-cowpea cropping systems in Conservation Agriculture (CA) and their relationship to biological nitrogen fixation capabilities of cowpea. Soils from Kayowozi Agriculture Camp of Chipata District of Zambia where CA had been practiced for six years were evaluated. Cropping systems studied included conventional tillage (control), maize monocropping (sole maize), maize-cowpea intercrop, maize-cowpea rotation: maize phase and maize-cowpea: cowpea phase. Standard laboratory procedures were used to determine the changes in the selected soil properties as a result of these cropping sequences under CA. The study showed that maizecowpea intercrop and rotation-maize phase under conservation agriculture could result in a significant increase in soil organic carbon, total nitrogen and exchangeable calcium after six years of practice. This increase can be associated with the amount and type of residue retained and the contribution of biologically fixed nitrogen from the cowpea. Having cowpea as the immediate previous crop in sequence can result in a depression of soil $\mathrm{pH}$. Soil $\mathrm{pH}$, total nitrogen, available phosphorus and exchangeable calcium in maize-cowpea cropping sequences can influence the amount of biologically fixed nitrogen. Changes in soil activity and microbial biomass might need more than six years to be apparent. The sequencing pattern of crops in a rotation, the choices and characteristics of crops, and the length of time of practice, all play an important role in determining interactions and processes leading to changes in soil properties and crop performance over time.
\end{abstract}

Keywords: biological nitrogen fixation, conservation agriculture, cowpea, soil microbial biomass

\section{Introduction}

Conservation agriculture (CA) in Zambia has been promoted since 1995 to address low soil fertility levels negatively impacting crop productivity and to encourage more sustainable land management practices by the Conservation Farming Unit of the Zambia National Farmers Union (Giller, Witter, Corbeels, \& Tittonel, 2009). Today, CA in Zambia is known as one of the success stories for its large-scale introduction and adoption among between 70,000 and 120,000 smallholder farmers (Haggblade \& Tembo, 2003). It combines the following three basic principles: (a) minimal soil disturbance by tillage; (b) permanent cover of the soil with organic matter provided by residue retention from the previous crop, fallow or by living cover crops; (c) diversified crop rotations that include $\mathrm{N}$-fixing legumes to maintain biodiversity above and below the soil to avoid the buildup of pest population within the spectrum of the soil inhabitants (Harrington \& Erenstein, 2005). CA removes the emphasis from the tillage component alone and addresses a more enhanced concept of the complete agricultural system. CA is a system of principles and practices aimed at achieving sustainability of agricultural production systems (Kassam et al., 2009).

CA systems are currently being practiced on a wide range of soil types, environments and on numerous crops and cropping systems (Kassam \& Friedrich, 2010) and therefore, CA seems to have a wide adaptation. The practice of CA has potential to reduce the requirements for labor and other inputs, to increase crop yields and to restore/preserve soil health (Novas, 2015). Because of its potential to increase productivity and address issues of food and nutrition security, CA has become an essential component of the national policies for agriculture and has received much attention from non-government organizations (Whitfield et al., 2015). 
The adoption of CA and all its practices has depended on the supply of provision of input packages and concomitant provision of close extension service support, resulting in disadoptions when these are withdrawn. In addition, adoption of CA comes with it some uncertainty surrounding the markets for cover, inter or rotation crops; the multiple uses and ensuing competition for crop residues; and the opportunity cost associated with leaving the land fallow. This together with other socio-economic factors affecting a particular farmer, has led to partial adoptions of the principles of CA in specific instances, requiring an investigation of accrued benefits under such circumstances. Further, while many on-station and on-farm trials have been conducted to evaluate changes in soil properties and crop yield, there is still only partial understanding of the interactions of different tillage practices, cropping sequences, soil cover types and properties, crop residue properties, soil macro- and micro fauna, and underlying mechanisms of nutrient cycling (Whitfield et al., 2015). Previous research on the effects of CA on soil properties in Zambia have suggested that changes in soil chemical and biological properties may take many years before they are evident (Muchabi, Lungu, \& Mweetwa, 2014); these changes must go through particular phases which also are strongly influenced by farmer practice. The lack of quick results could be a discouraging factor leading to disadoptions and therefore, presenting a need for farmer sensitization of this aspect of CA adoption.

The different combinations of practice and their interactions with bio-physical factors present knowledge gaps in accrued benefits and their underlying mechanisms. This paper reports results from an evaluation of selected soil chemical and biological properties under partial CA adoption for six years. The paper focuses specifically on maize-cowpea cropping sequences and their effects on soil properties and biological nitrogen fixation capabilities of cowpea. The paper builds on earlier work in Zambia that show the influence of length of time of practice (Muchabi et al., 2014) and cropping sequences (Thierfelder, Cheesman, \& Rusinamhodzi, 2012) on soil chemical, physical and biological properties under CA.

\section{Materials and Methods}

\subsection{Study Area Description}

The study was conducted in Kayowozi Agriculture Camp in Chipata District, which is located at longitude $13.70^{\circ} \mathrm{S}$, and latitude $32.61^{\circ} \mathrm{E}$ with an altitude of $1070 \mathrm{~m}$ above sea level in agro-ecological region IIa of Zambia. This region receives an annual rainfall of 800 to $1000 \mathrm{~mm}$. The soils in this Camp are predominantly Acrisols and Alisols (WRB, 1998). The major crops grown are maize, cotton, cowpeas, common beans and groundnuts. This site was selected for this study because it had been under CA for the previous six (6) years. In this Camp, farmers were practicing conventional tillage, maize monocropping, maize-cowpea rotations, and maize-cowpea inter-copping. All the six farmers in the Camp were practicing these and were therefore, included in the study. Additionally, the maize-cowpea rotations in alternate phases were treated as different practices or treatments in this study. Together, experimental sites included were conventional tillage (control), maize monocropping (sole maize), maize-cowpea intercrop, maize-cowpea rotation: maize phase and maize-cowpea rotation: cowpea phase. The sequencing of the rotation was maize first then cowpea and cowpea first then maize, in that order for six consecutive seasons; meaning that maize crop had immediately been harvested before the study for the maize-cowpea: maize phase and the opposite was true for the cowpea phase.

\subsection{Soil Sampling and Analytical Procedures}

The soils were collected from each site from each farmer's field (conventional tillage, CA-sole maize, CA-maize/cowpea intercropped, CA-maize/cowpea rotation (maize phase) and CA-maize/cowpea rotation (cowpea phase). Each farmer represented a replicate. From each site, five (5) sub soil samples were collected in replicates of three from depths of $0-20 \mathrm{~cm}$ in a radial sampling scheme using an auger (Wilding, 1985). In total, 30 soil samples were collected from the five cropping sequences and six farmer fields.

Soils were then subjected to both chemical and biological analyses. The soil samples were analyzed for; soil reaction (Van Reeuwijk, 1992) available phosphorus (Olsen, Cole, Watanabe, \& Dean, 1954), total nitrogen (Bremner \& Mulvaney, 1982), soil organic carbon (Walkley \& Black, 1934), exchangeable bases $\left(\mathrm{K}^{+}, \mathrm{Mg}^{2+}\right.$ and $\left.\mathrm{Ca}^{2+}\right)$ (Rowell, 1994) and soil microbial biomass (Jenkinson \& Powlson, 1976).

\subsection{Determination of Cowpea Biological Nitrogen Fixation}

In order to determine the nitrogen capabilities of the cowpea crop in soils derived from these cropping sequences, a greenhouse experiment was setup arranged in a Completely Randomized Design. The five cropping sequences were the treatments, and each one replicated three times for each farmer. Lutembwe cowpea variety was planted and pearl millet as a reference crop in pots with $5 \mathrm{~kg}$ soil. After 14 days of germination, cowpea was thinned to one plant per pot whilst pearl millet to two plants per pot. The above ground biomass was later harvested at 7 
weeks for both crops and the total nitrogen fixed was determined using the Nitrogen Difference Method (Unkovich et al., 2008).

\subsection{Statistical Analysis}

To determine the effects of the cropping sequences on soil microbial biomass, soil respiration, soil chemical characteristics and biologically fixed nitrogen in cowpea, analyses of variance were done using SAS Package Version 9.0 at $95 \%$ confidence level. Means were separated based on the least significance difference (LSD) approach at $0.05 \%$.

\section{Results}

\subsection{Effect of Cropping Sequence on Selected Soil Chemical Properties}

In this study, soil organic carbon (SOC) in the soils ranged from 0.91 to $1.08 \%$ (Figure 1). Significant differences among cropping sequences were observed only between conventional, and intercrop and rotation-maize phase. The rotation-maize phase had the highest amount of SOC (1.08\%). SOC in the intercrop and the rotation-maize phase was 17 and $25 \%$ higher than in the conventional, respectively. In comparison to the sole maize (maize monocropping) and intercrop, rotation-maize phase had 8 and 14\% more SOC, respectively, after six years of CA practice.

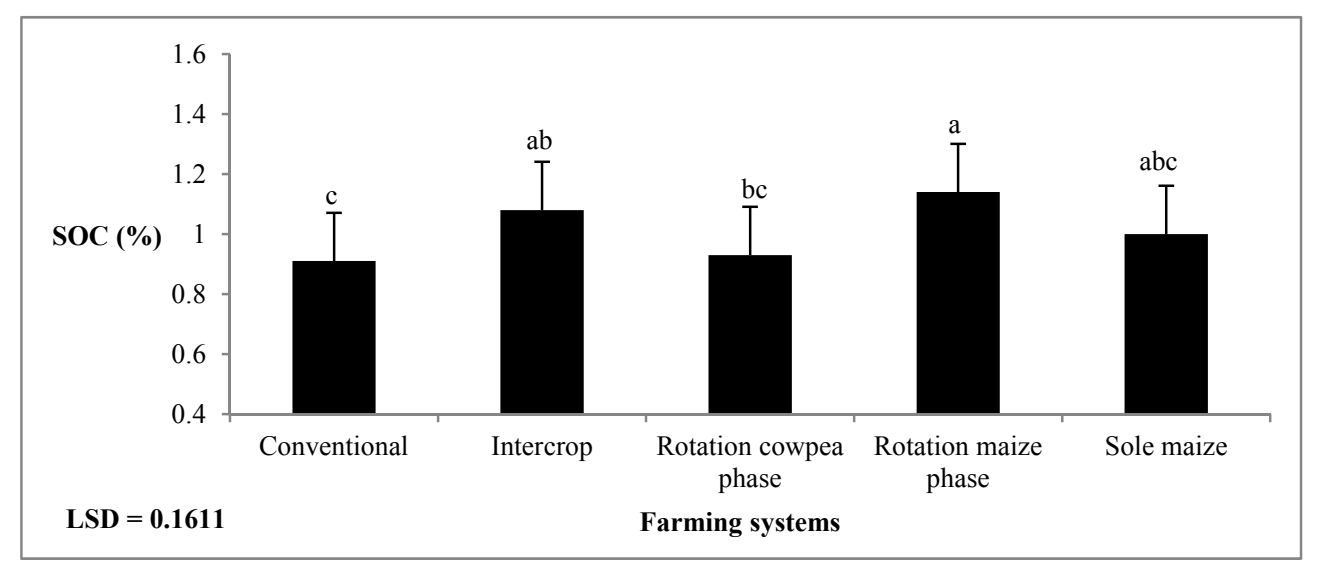

Figure 1. Soil Organic Carbon (SOC; \%) in soils under maize-cowpea intercrop and rotation cropping systems after six years of CA practice

Note. Error bars indicate least significant difference $(\mathrm{n}=6)$.

The levels of total $\mathrm{N}$ in soils ranged from 0.09 to $0.10 \%$. Highest levels of total $\mathrm{N}$ were observed in the intercrop and rotation-maize phase cropping sequences with $0.10 \%$. The others; conventional, rotation-cowpea phase and sole maize cropping systems had significantly lower total $\mathrm{N}(0.09 \%)$. This pattern followed that observed for SOC, although the differences between the highest and lowest total $\mathrm{N}$ levels were only by $10 \%$. In general, total $\mathrm{N}$ was highest where legumes were included in the cropping sequence.

The soil $\mathrm{pH}$ ranged from 5.02 to 5.19 with a mean of 5.13. Cropping sequence had a significant effect on soil reaction (Figure 3). Rotation-maize phase had a significantly higher soil pH (5.19) than all the other cropping sequences followed by sole maize (5.13). 


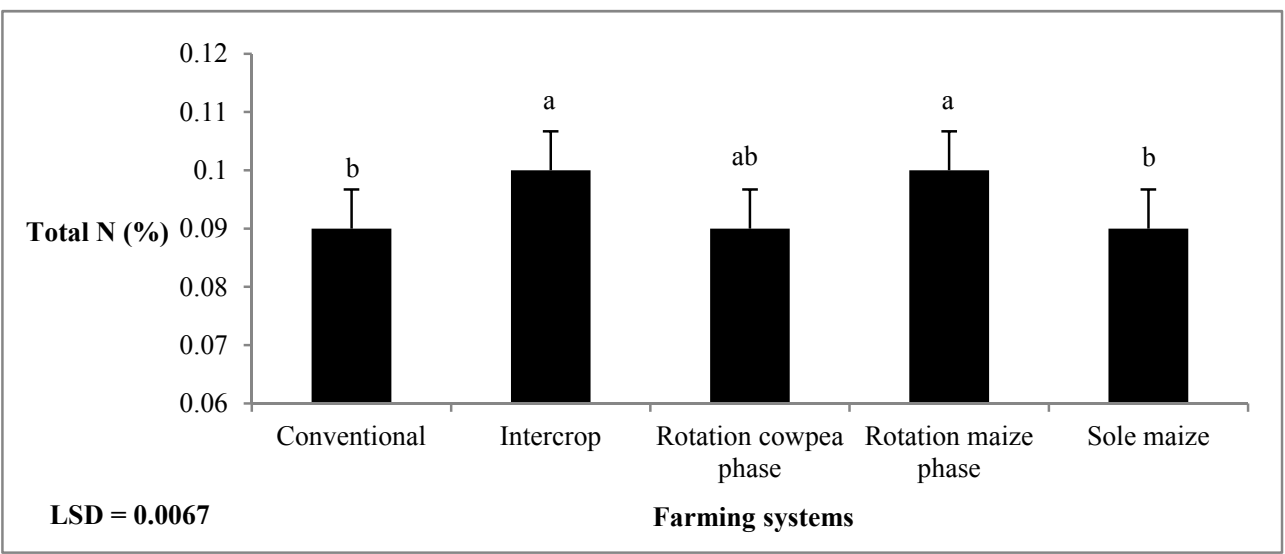

Figure 2. Effect of maize-cowpea cropping sequences on total nitrogen (\%) in soils under six years of CA Note. Error bars indicate least significant difference $(n=6)$.

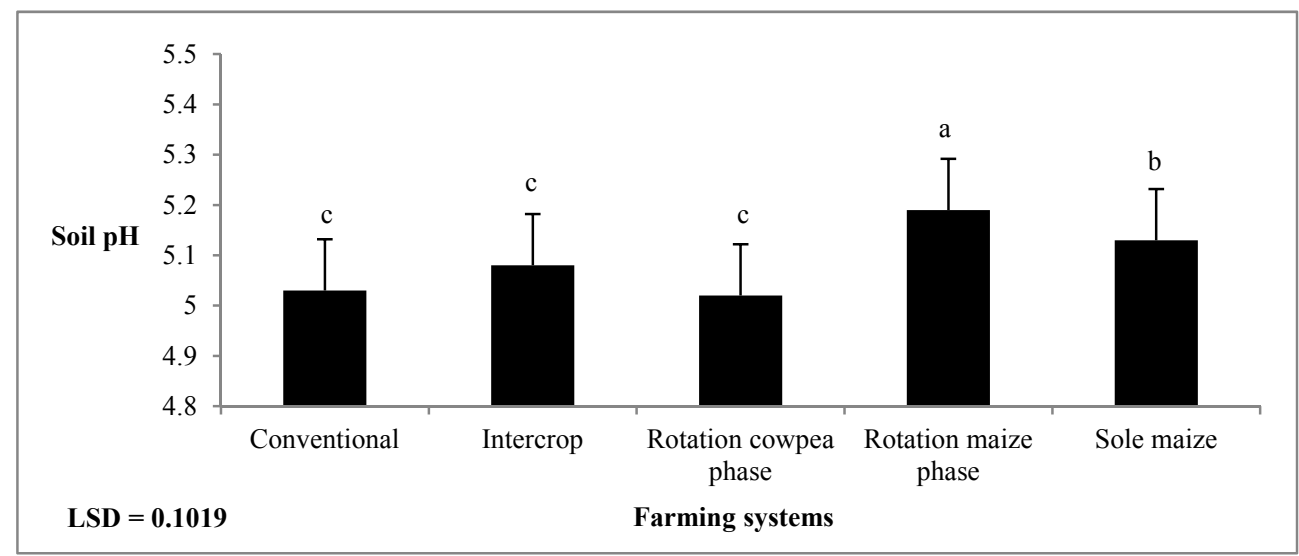

Figure 3. Soil reaction in maize-cowpea cropping sequences after six years of CA practice

Note. Error bars indicate least significant difference $(\mathrm{n}=6)$.

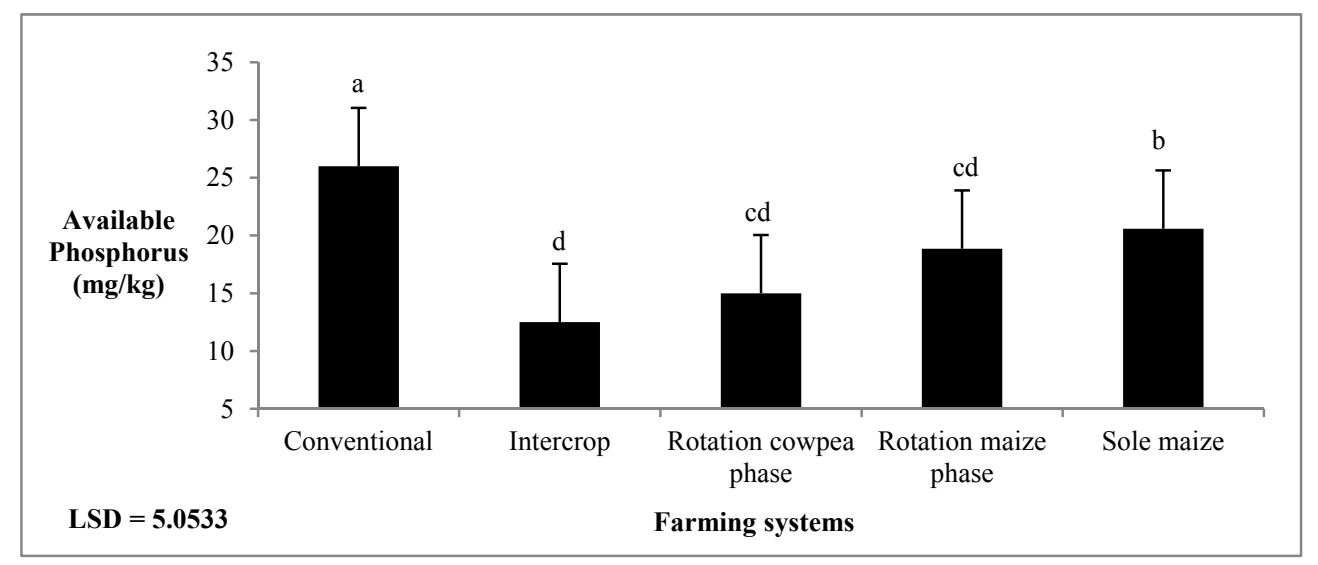

Figure 4. The concentration of available Phosphorus $(\mathrm{mg} / \mathrm{kg})$ in soils under 6 years of CA systems Note. Error bars indicate least significant difference $(n=6)$. 
The results showed significant differences between conventional and the rest of the cropping systems. Conventional had the highest available phosphorus $(25.99 \mathrm{mg} / \mathrm{kg})$ followed by sole maize $(20.28 \mathrm{mg} / \mathrm{kg})$. Compared to the conventional, sole maize had $20.8 \%$ less available phosphorus. The results show a lack of significant differences among the other cropping sequences involving cowpea and a significant reduction in available $\mathrm{P}$ compared to the conventional.

The levels of $\mathrm{K}^{+}$and $\mathrm{Mg}^{2+}$ were not significantly affected by cropping sequence but were above the $0.20 \mathrm{cmol}(+)$ $/ \mathrm{kg}$ critical limit for productive plant growth (Fairhurst, 2012). On the other hand, $\mathrm{Ca}^{2+}$ levels were highest in the rotation-maize phase and sole maize cropping sequences but were not significantly different from the intercrop (Table 1). Rotation-cowpea phase showed no difference in $\mathrm{Ca}^{2+}$ levels from the conventional.

Table 1. Effect of cropping sequences on exchangeable bases in soils under six years of CA practice $(n=6)$

\begin{tabular}{llll}
\hline \multirow{2}{*}{ Practice } & \multicolumn{3}{c}{ Exchangeable Bases (cmol (+)/kg soil) } \\
\cline { 2 - 4 } & $\mathbf{K}^{+}$ & $\mathbf{C a}^{\mathbf{2}}$ & $\mathbf{M g}^{\mathbf{2}}$ \\
\hline Conventional & $0.69^{\mathrm{a}}$ & $2.49^{\mathrm{b}}$ & $0.85^{\mathrm{a}}$ \\
Intercrop & $0.81^{\mathrm{a}}$ & $2.72^{\mathrm{ab}}$ & $0.99^{\mathrm{a}}$ \\
Rotation Cowpea Phase & $0.73^{\mathrm{a}}$ & $2.49^{\mathrm{b}}$ & $0.99^{\mathrm{a}}$ \\
Rotation Maize Phase & $0.70^{\mathrm{a}}$ & $3.24^{\mathrm{a}}$ & $0.91^{\mathrm{a}}$ \\
Sole Maize & $0.71^{\mathrm{a}}$ & $3.25^{\mathrm{a}}$ & $1.03^{\mathrm{a}}$ \\
LSD (0.05) & 0.1512 & 0.6084 & 0.2268 \\
$p$ value & 0.5723 & 0.0204 & 0.5569 \\
\hline
\end{tabular}

Note. Means with the same letter are not significantly different at the $p=0.05$ level.

\subsection{Effect of Cropping Sequence on Soil Microbial Biomass, Soil Activity and Biological Nitrogen of Cowpea}

Cropping sequence did not significantly affect soil respiration levels (Table 2). In general, microbial activity was higher under conventional tillage systems than in CA. Though not significantly different from the conventional, intercrop and sole maize, maize-cowpea rotation systems had higher soil microbial biomass carbon. The levels of soil microbial biomass-C (MBC) in this study ranged from 1.96 to $2.28 \mathrm{mg} / \mathrm{g}$.

Table 2. Soil microbial biomass and activity concentrations in soil under 6 years of CA systems $(n=6)$

\begin{tabular}{lll}
\hline Practice & Respiration carbon $(\mathbf{m g} / \mathbf{g})$ & MBC $(\mathbf{m g} / \mathbf{g})$ \\
\hline Conventional & $0.58^{\mathrm{a}}$ & $2.10^{\mathrm{a}}$ \\
Intercrop & $0.54^{\mathrm{a}}$ & $1.96^{\mathrm{a}}$ \\
Rotation Cowpea Phase & $0.48^{\mathrm{a}}$ & $2.28^{\mathrm{a}}$ \\
Rotation Maize Phase & $0.45^{\mathrm{a}}$ & $2.28^{\mathrm{a}}$ \\
Sole Maize & $0.55^{\mathrm{a}}$ & $2.07^{\mathrm{a}}$ \\
Lsd (0.05) & 0.1843 & 0.6742 \\
$p$ value & 0.6079 & 0.845 \\
\hline
\end{tabular}

Note. Means with the same letter are not significantly different at the $p=0.05$ level.

Biologically fixed nitrogen of cowpea was highest in soils from the sole maize $(1.3 \% \mathrm{~N})$, followed by rotation-maize phase $(1.24 \% \mathrm{~N})$ and conventional $(1.17 \% \mathrm{~N})$ systems. Significant differences in biological nitrogen fixation of cowpea were observed only between sole maize and intercrop and also between sole maize and rotation cowpea-phase (Figure 5). Biological nitrogen fixed ranged from 1.02 to $1.30 \%$ with an average of $1.16 \%$. The results show the reduced capability of nitrogen fixation in soils planted to intercrop and rotation-cowpea phase by 13 and $9 \%$ (not significant). 


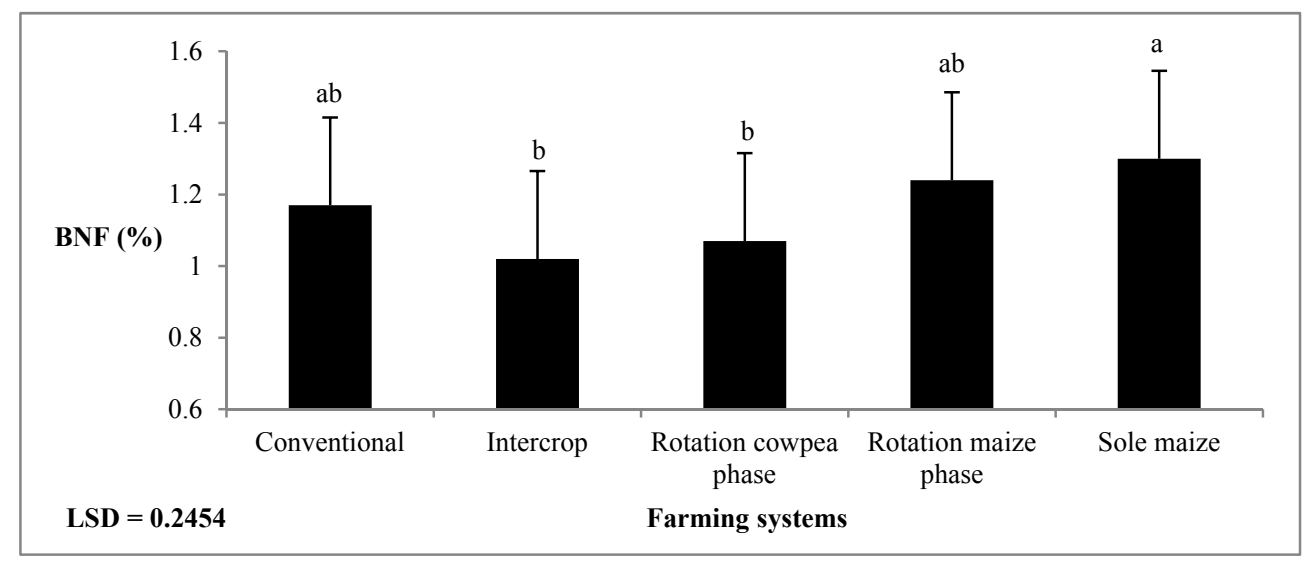

Figure 5. Biological nitrogen fixation of the soils under 6 years of CA systems

Note. Error bars indicate least significant difference $(\mathrm{n}=6)$.

\section{Discussion}

All SOC levels observed were below the critical limit of $1.5 \%$ for crop productivity (Fairhurst, 2012). Studies conducted earlier suggested that accumulation of SOC depends on the length of time under CA practice and amount of organic matter retained on the soil (Blanco-Canqui \& Lal, 2007). Higher amounts of crop residues retained result in higher concentrations of SOC (Dolan, Clapp, Allmaras, Baker, \& Molina, 2006). Maize crops produce higher amounts of above ground biomass than cowpea resulting in a larger amount of crop residues being retained. This could account for the observed higher SOC content in the rotation maize-phase and intercrop than in all the other practices. A wider $\mathrm{C}: \mathrm{N}$ ratio results in a lower rate of mineralization leading to accumulation SOC (Trinsoutrot et al., 2000). Maize stover has a wide C:N ratio of 60-100:1 (Connor, Loomis, \& Cassman, 2011) compared to cowpea which has a C:N ratio of only 21:1 (Nyle, 1991). This might explain partially why all cropping systems having maize in the immediate season had more SOC under CA. The implication is that the faster the crop residues are consumed by soil microorganisms, the less time these residues cover the soil surface and the lower the SOC accumulated over time. This is important when considering the function and choices of residues in $\mathrm{CA}$. In addition, complete soil tillage and the addition of inorganic $\mathrm{N}$ fertilizers also accelerate the process of residue decomposition leading to lower SOC accumulation in soils. This can be observed under the conventional cropping system in this study. Length of time under CA practice is also an essential factor determining SOC accumulation over time (Blanco-Canqui \& Lal, 2007). Studies by Umar et al. (2011) and Muchabi et al. (2014) in Lusaka, Eastern, Southern and Central provinces of Zambia suggested that five years of CA practice would not be long enough for the effects to be significant but waiting for seven years would result in sufficient SOC accumulation. That this soil had been under CA practice for only six years could explain why SOC levels were still low and, in some cases, not significantly higher than under conventional farming.

Generally, the effect of CA on total N content is somewhat similar to that of SOC as the cycles are linked (Bradford \& Peterson, 2000). Most of the CA soils were high in N concentrations but lower than $0.15 \%$ which is the optimal for plant growth (Fairhurst, 2012). Levels of total $\mathrm{N}$ were found to be higher when cowpea was part of the cropping system because of the contribution of $\mathrm{N}$ to the soil through nitrogen fixation. The lower levels of total $\mathrm{N}$ in the conventional and sole maize systems could partially explain the higher amounts of biologically fixed nitrogen observed in these systems. Biological nitrogen fixation is affected by many factors including the amount of mineralizable N (Gupta, 1998). At higher levels of mineralizable N, rhizobia infection of root hairs, nodule initiation and nitrogenase enzyme activity are inhibited resulting in lower amounts of nitrogen fixed. Therefore, when levels of soil nitrogen are sufficient, nodulation is inhibited and existing nodules can degrade (Otieno, Muthomi, Cheminig'wa, \& Nderitu, 1997). In addition, available Phosphorus, and soil pH both affect biological nitrogen fixation (Gupta, 1998). In this study, the amounts of biologically fixed nitrogen in the different cropping sequences were positively but moderately correlated with the levels of soil reaction and the amounts of available Phosphorus ( $\mathrm{r}=0.62$ and 0.64 , respectively; data not shown). The moderate relationship between soil reaction and amount of nitrogen fixed could be due to the fact the $\mathrm{pH}$ of the soils was outside the range considered optimum for nodulation of cowpea (Joe \& Allen, 2008) for all cropping sequences. Soil pH 
affects biological nitrogen fixation by directly affecting the host legume, the microorganism, the interaction between the two, and the availability of calcium and molybdenum (Ferguson, Lin, \& Gresshoff, 2013). Rhizobia abundance, survival and competitiveness are all very sensitive to soil $\mathrm{pH}$ (Joe \& Allen, 2008). The pattern of soil $\mathrm{pH}$ observed in this study was similar to that of accumulated SOC with a strong correlation of $\mathrm{r}=0.8451$ (data not shown). The low SOC levels in conventional and rotation- cowpea phase could have led to reduced $\mathrm{pH}$ buffering capacity, and hence lower pH levels (Duiker \& Beegle, 2006). In addition, the higher uptake of cations by legumes through the proton-antiport mechanism to meet the plant development demands leads to the lowering of $\mathrm{pH}$ in soils (Haynes, 1983).

In this study, amount of available phosphorus was significantly lower in cropping sequences including cowpea; following the pattern of the amount of nitrogen fixed. There was a positive but moderate relationship with the amount of nitrogen fixed at $r=0.64$ (data not shown). The lower amounts of available phosphorus observed in the cropping sequences with cowpea could be attributed to the fact legumes tend to have a high phosphorus requirement to meet the needs for biological nitrogen fixation resulting in its depletion in the rhizosphere. Phosphorus plays a significant role in determining the energy budget of the symbiosome in the form of ATP (Mweetwa, Chilombo, \& Gondwe, 2016). In biological nitrogen fixation, phosphorus is critical for nodule formation and functioning as well as for specific nitrogenase activity (Kouas, Labidi, Debez, \& Abdelly, 2005).

The exchangeable bases, $\mathrm{Mg}^{2+}$ and $\mathrm{K}^{+}$, were not significantly affected by the cropping sequence but were above the critical level of $0.20 \mathrm{cmol}(+) / \mathrm{kg}$ required for productive growth (Fairhurst, 2012). Ca ${ }^{2+}$ was highest in the cropping sequences having the most SOC. Levels of exchangeable bases have previously been associated with SOC, such that lack of restitution of crop residues contributes to a significant decrease in exchangeable soil bases and an increase in soil acidification (Bationo, Waswa, Kihara, \& Kimetu, 2007). In this study, the relationship between SOC and $\mathrm{Ca}^{2+}$ was $\mathrm{r}=0.68$ (data not shown). The availability of $\mathrm{Ca}^{2+}$ in a soil cropped to a legume affects the amount of nitrogen fixed. Specifically, $\mathrm{Ca}^{2+}$ affects attachment of rhizobia to root hairs, nodulation and nodule development (Weisany, Raei \& Allahverdipoor, 2013). To this effect, there was a strong positive relationship between $\mathrm{Ca}^{2+}$ and the amount of biologically fixed nitrogen $(\mathrm{r}=0.818$; data not shown). Suffice to say that the amount of $\mathrm{Ca}^{2+}$ in all soils was above the critical limit of $0.5 \mathrm{cmol}(+) / \mathrm{kg}$ required for productive crop growth (Fairhurst, 2012).

While soil microbial biomass (SMB) represents about $2-7 \%$ of soil organic matter, and the amount of organic matter positively affects soil activity, these relationships were not apparent in the current study. Cropping sequence did not influence soil microbial biomass or activity. Earlier findings have shown that significant changes in soil microbial biomass in soils under CA are apparent only after 16 years of practice (Muchabi et al., 2014); this suggests that the length of time of practice in this case being only six years might have been too short to elicit observable changes.

\section{Conclusion}

The cropping sequences involving maize-cowpea intercrop and rotation-maize phase under conservation agriculture can result in a significant increase in soil organic carbon, exchangeable calcium and total nitrogen after six years of practice. This increase in SOC, exchangeable calcium and total nitrogen can be associated with the amount and type of residue retained and the contribution of biologically fixed nitrogen from the cowpea, respectively. Having cowpea as the immediate previous crop in sequence can result in a depression of soil $\mathrm{pH}$ due to high uptake of exchangeable bases and low soil organic carbon in that system. Soil $\mathrm{pH}$, total nitrogen, available phosphorus and exchangeable calcium in maize-cowpea cropping sequences can influence the amount of biologically fixed nitrogen. Changes in soil activity and microbial biomass might need more than six years to be apparent. All these put together, suggest that the sequencing pattern of crops in a rotation, the choices and characteristics of crops in a system, and the length of time of practice, all play an important role in determining interactions and processes that lead to changes in soil properties and crop performance over time.

\section{Acknowledgements}

We acknowledge the logistical support of the International Maize and Wheat Improvement Centre (CIMMYT) to the research project which was embedded in the MAIZE CGIAR Research Program (www.maize.org). Financial support was received by the USAID-funded project "Sustainable Intensification in Maize-legume systems in Eastern Zambia (SIMLEZA)", award number: EEM-G-00-04-00013-00 given to CIMMYT. 


\section{References}

Bationo, A., Waswa, B., Kihara, J., \& Kimetu, J. (2007). Advances in Integrated Soil Fertility Management in Sub-Saharan Africa: Challenges and Opportunities. Springer Publishers, Netherlands. https://doi.org/ 10.1007/978-90-481-2543-2_1

Blanco-Canqui, H., \& Lal, R. (2007). Impacts of long-term wheat straw management on soil hydraulic properties under no-tillage. Soil Science Society of America Journal, 71, 1166-1173. https://doi.org/10.2136/sssaj 2006.0411

Bradford, J. M., \& Peterson, G. A. (2000). Conservation tillage. In M. E. Sumner (Ed.), Handbook of Soil Science (pp. G247-G269). Boca Raton, FL, USA: CRC Press.

Bremner, J. M., \& Mulvaney, C. S. (1982). Nitrogen-Total. In A. L. Page, R. H. Miller, \& D. R. Keeney (Eds.), Methods of soil analysis, Part 2: Chemical and Microbiological properties (2nd ed.). ASA, SSA, Madison, Wisconsin, USA.

Connor, D. J., Loomis, R. S., \& Cassman, K. G. (2011). Crop ecology: Productivity and management of agricultural systems (2nd ed.). Cambridge University Press, UK. https://doi.org/10.1017/CBO97805119 74199

Dolan, M. S., Clapp, C. E., Allmaras, R. R., Baker, J. M., \& Molina, J. A. E. (2006). Soil organic carbon and nitrogen in Minnesota, soil as related to tillage, residue and nitrogen management. Soil and Tillage Research, 89, 221-231. https://doi.org/10.1016/j.still.2005.07.015

Duiker, S. W., \& Beegle, D. B. (2006). Soil fertility distributions in long-term no-till, chisel/disk and moldboard plow/disk systems. Soil and Tillage Research, 88, 30-41. https://doi.org/10.1016/j.still.2005.04.004

Fairhurst, T. (2012). Handbook for integrated soil fertility management. Africa soil health consortium. CAB International, SPi, Pondicherry, India.

Ferguson, B. J., Lin, M.-H., \& Gresshoff, P. M. (2013). Regulation of legume nodulation by acidic growth conditions. Plant Signaling \& Behavior, 8(3), e23426. https://doi.org/10.4161/psb.23426

Giller, K. E., Witter, E., Corbeels, M., \& Tittonel, P. (2009). Conservasion agriculture and small holder farming in Africa: The heretics' view. Field Crops Research, 11(1), 23-34. https://doi.org/10.1016/j.fcr.2009.06.017

Gupta, V. V. S. R. (1998). The living soil: soil microorganisms and their role in soil processes. Proceedings of the 9th Australian cotton conference broad beach, Queensland, SA.

Haggblade, S., \& Tembo, G. (2003). Early Evidence on Conservation Farming in Zambia. A paper prepared for the international workshop on Reconciling Rural poverty and resource conservation; Identifying Relationships and Remedies, Cornwell University, Ithaca, New York.

Harrington, L., \& Erenstein, O. (2005). Conservation agriculture and resource conserving technologies-A global perspective. Agromeridian, 1(1), 32-43.

Haynes, R. J. (1983). Soil acidification induced by leguminous crops. Grass and Forage Science, $38,1-11$. https://doi.org/10.1111/j.1365-2494.1983.tb01614.x

Jenkinson, D. S., \& Powlson, D. S. (1976). The effects of boicidal treatments on metabolism in soil. V. A method for measuring soil biomass. Soil Biology and Biochemistry, 8, 209-213.

Joe, W. H., \& Allen, J. R. (2008). Effect of soil pH on plant growth and nodulation of cowpea. Communications in Soil Science and Plant Analysis, 11(11), 1077-1085. https://doi.org/10.1080/00103628009367106

Kouas, S., Labidi, N., Debez, A., \& Abdelly, C. (2005). Effect of P on nodule formation and N fixation in bean. Agron. Sustain. Dev., 25, 389-393. https://doi.org/10.1051/agro:2005034

Muchabi, J., Mweetwa, A. M., \& Lungu, O. I. (2014). Conservation Agriculture in Zambia: Effects on selected Soil properties and Biological Nitrogen Fixation in Soya Beans (Glycine max (L.) Merr). Sustainable Agriculture Research, 3, 28-36. http://dx.doi.org/10.5539/sar.v3n3p28

Mweetwa, A. M., Chilombo, G., \& Gondwe, B. M. (2016). Nodulation, nutrient uptake and yield of common bean inoculated with Rhizobia and Trichoderma in an acid soil. Journal of Agricultural Science, 8(12), 61-71. https://doi.org/10.5539/jas.v8n12p61

Novas, S. A. (2015). Climate Change Adaptation Measures in Agriculture: ACase of Conservation Agriculture for Small-Scale Famers in Kalomo District of Zambia (Master's thesis, University of Cape Town, Cape 
Town, South Africa). Retrieved from https://open.uct.ac.za/bitstream/handle/11427/15725/thesis_sci_2015_ somanje_albert_novas.pdf? sequence $=1$

Nyle, C. B. (1991). Advanced in agronomy (Vol. 45). Academic Press, Inc San Diego, California.

Olsen, S. R., Cole, C. V., Watanabe, F. S., \& Dean, L. A. (1954). Estimation of available phosphorus in soil by extraction with sodium bicarbonate. USDA Circular.

Otieno, P. E., Muthomi, J. W., Cheminig'wa, G. N., \& Nderitu, J. H. (2007). Effect of rhizobia inoculation, farmyard manure and nitrogen fertilizer on growth, nodulation and yield of selected grain legumes. African Crop Science Conference Proceedings, 8, 305-312.

Rowell, D. L. (1994). Soil science: Methods and Applications. Addison Wesley Longman Singapore Publishers (pte) Ltd., England, UK.

Thierfelder, C., Cheesman, S., \& Rusinamhodzi, L. (2012). Benefits and challenges of crop rotations in maize-based conservation agriculture (CA) cropping systems of southern Africa. International Journal of Agricultural Sustainability, 11(2), 108-124. https://doi.org/10.1080/14735903.2012.703894

Trinsoutrot, I., Recous, S., Bentz, B., Lineres, M., Cheneby, D., \& Nicolardot, B. (2000). Biochemical quality of crop residues and carbon and nitrogen mineralization kinetics under non-limiting nitrogen conditions. Soil Science Society of America Journal, 64, 918-926. https://doi.org/10.2136/sssaj2000.643918x

Umar, B. B., Aune, B. J., Johnsen, H. F., \& Lungu, I. O. (2011). Options for improving smallholder conservation agriculture in Zambia. Journal of Agricultural Science, 3(3), 50-62. https://doi.org/10.5539/jas.v3n3p50

Unkovich, M., Herridge, D., Peoples, M., Cadisch, G., Boddey, B., Giller, K., ... Chalk, P. (2008). Measuring plant-associated nitrogen fixation in agricultural systems. ACIAR.

USDA. (1998). Soil quality test kit. Agricultural Research Service, Washington DC, USA.

Van Reeuwijk, L. P. (1992). Proceedings for soil Analysis (3rd ed.). International Soil Reference and Information Center (ISRIC), Wageningen, the Netherlands.

Walkley, A., \& Black, I. A. (1934). An examination of the Degtjareff method for determining soil organic matter and a proposed modification of the chromic acid titration method. Soil Science, 37(1), 29-38. https://doi.org/10.1097/00010694-193401000-00003

Weisany, W., Raei, Y., \& Allahverdipoor, K. H. (2013). Role of mineral nutrients in Biological nitrogen fixation. BEPLS, 2(4), 77-84.

Whitfield, S., Dougill, A., Dyer, J. C., Kalaba, F. K., Leventon, J., \& Stringer, L. C. (2015). Critical reflection on knowledge and narratives of conservation agriculture. Geoforum, 60, 133-142. https://doi.org/10.1016/ j.geoforum.2015.01.016

Wilding, L. G. (1985). Soil Spatial Variability: Its documentation, accommodation and implication to soil surveys. Soil spatial variability proceedings of a workshop of the ISSS and the SSA, Las Vegas PUDOC, Wageningen.

WRB. (1998). World Reference Base on Soils. FAO-ISRIC, Rome, Italy.

\section{Copyrights}

Copyright for this article is retained by the author(s), with first publication rights granted to the journal.

This is an open-access article distributed under the terms and conditions of the Creative Commons Attribution license (http://creativecommons.org/licenses/by/4.0/). 